Proc. Estonian Acad. Sci. Biol. Ecol., 2004, 53, 4, 292-305

\title{
Microevolution of eelpout, Zoarces viviparus, in the Baltic Sea
}

\author{
Henn Ojaveer ${ }^{\mathrm{a} *}$, Margit Eero ${ }^{\mathrm{b}}$, and Ain Lankov ${ }^{\mathrm{a}}$ \\ ${ }^{a}$ Estonian Marine Institute, University of Tartu, Mäealuse 10a, 12618 Tallinn, Estonia \\ ${ }^{\mathrm{b}}$ Danish Institute for Fisheries Research, Charlottenlund Slot, DK-2920 Charlottenlund, Denmark
}

Received 10 March 2004, in revised form 23 August 2004

\begin{abstract}
Zoarces viviparus was sampled in various sub-basins of the Baltic Sea (Gulf of Finland, Gulf of Riga, and Baltic Proper) by different biotopes (eurytherm, cold stenotherm, and their transition areas). The somatic growth rate, absolute fecundity, and number of vertebrae differed significantly between the biotopes suggesting the existence of different eelpout populations in the northeastern Baltic. Adaptation of the originally cold stenotherm eelpout enabled the fish to occupy the more productive eurytherm biotope and thus facilitated an increase in the abundance of the species. An important precondition for this was the existence of transitional abiotic conditions that promoted the break of the species through the temperature barrier, but also simultaneous or earlier adaptation of the cold stenotherm invertebrate prey complex to the eurytherm conditions. As a result of adaptations, the phenotype of the species has changed compared to the original (stenotherm) stock. Adaptation of the fish to new conditions has not caused changes in its intraovarian growth.
\end{abstract}

Key words: Eelpout, Zoarces viviparus, cold stenotherm and eurytherm environment, growth rate, fecundity, number of vertebrae, diet composition, adaptation.

\section{INTRODUCTION}

The formation of the biota of the Baltic Sea started after the last glaciation that ended approximately $10000-15000$ years ago. The main components of the Baltic biota are natural immigrants from adjacent waterbodies of different origin glacial relicts, marine boreal species, and freshwater organisms (Elmgren, 1984). The appearance and disappearance of broad connections with neighbouring waterbodies during different time periods of the development of the Baltic Sea probably led to several waves of immigration (Järvekülg, 1973).

\footnotetext{
* Corresponding author, henn@pc.parnu.ee
} 
Freshwater species mainly colonize the near-coastal areas with warm temperatures in summer above the seasonal thermocline and glacial relicts deeper areas with low temperatures beneath the thermocline (eurytherm and stenotherm biotopes, respectively). Marine boreal species are mostly confined to open and deeper areas with higher salinity. However, several species exhibit deviations in this general distribution pattern. For example, besides well-known herring (Clupea harengus membras), pipefish (Nerophis ophidion), which is of marine origin, is successfully adapted to low-salinity conditions and is abundantly found in productive river mouths (Ojaveer, 1997). Similarly, the ice-age relict Saduria entomon is permanently found in the warm environment in shallow coastal areas (Gaumiga \& Lagzdinsh, 1995). In contrast, several glacial relict species such as Myoxocephalus quadricornis, Monoporeia femorata, Mysis relicta, and M. mixta are mostly confined to their original cold stenotherm environments (Järvekülg, 1968; Neuman, 1982; Kotta \& Kotta, 1999). During the periods of unfavourable environmental conditions there, these species suffer drastic stock abundance decreases (Gaumiga \& Lagzdinsh, 1995; Ojaveer et al., 1999).

Eelpout is a relatively common viviparous fish in the Baltic Sea inhabiting both shallow and deep areas (Draganik \& Kuczynski, 1993; Jacobsson et al., 1993). As the species exhibits certain essential features characteristic of glacial relicts (permanent presence in the cold environment, reproduction during the winter), it should be considered a glacial relict whose original population was probably confined to the cold-stenotherm biotope. As the water layers of this environment can frequently face oxygen deficiency, the fish should be adapted to environmental hypoxia and be able to survive over short anoxic periods (Fisher et al., 1992). This may point to a wide adaptability range of this sedentary species to various or changing environmental conditions. Eelpout has shown considerable geographical variation both in meristic and genotypic indices (Schmidt, 1917; Hjorth \& Simonsen, 1976).

We investigated some important parameters of eelpout (intraovarian and postembryonal somatic growth, absolute fecundity, number of vertebrae, and diet composition) in different biotopes and their transition areas in various sub-basins of the Baltic Sea. The main aim of the study was to reveal the spatial dynamics and regularities of the selected indices of eelpout in order to understand the key requirements and driving forces for its intrusion into the shallow areas of the eurytherm biotope in the Baltic Sea.

\section{MATERIAL AND METHODS}

Eelpout was sampled in three sub-basins of the Baltic Sea - Gulf of Finland (GoF), Gulf of Riga (GoR), and Baltic Proper (BP). Samples were taken from two biotopes and their transition area: 1 - eurytherm biotope of a highly variable annual temperature regime with generally elevated biological productivity, mainly populated by organisms of freshwater origin and eurytherm euryhaline species. Within this biotope, the biological productivity level is the highest in the Gulf of 
Riga (GoR1), moderate in the Gulf of Finland (GoF1), and the lowest in the Baltic Proper (BP1). From this biotope, samples were taken at a 3-5 m depth. $2-$ cold stenotherm biotope beneath the seasonal thermocline. Within this biotope, two functionally different areas of different levels of secondary biological productivity were sampled: high-productivity areas at sharp slopes inhabited by marine boreal species and glacial relicts (BP2, at 70-75 m) and low-productivity locations mainly populated by crustaceans of arctic origin (GoF2 and GoR2, at $40-60 \mathrm{~m})$. The transition area between the two distinct biotopes, where the seasonal thermocline intersects the coastal slope (at 12-30 m), was studied in the Gulf of Finland and the Gulf of Riga (GoFtr and GoRtr, respectively) (Fig. 1).

The growth rate of eelpout was studied using data from 2117 fish caught in April-May 1994-1998 by the sub-regions/biotopes as follows: GoF1 274, GoFtr 278, GoF2 234, BP1 141, BP2 202, GoR1 237, GoRtr 423, and GoR2 328 fish. The age of fish was determined using sagittal otoliths according to interpretation of otolith structures by Svedäng et al. (1997). Sagittae of the fish from the eurytherm biotope and the transition area between different biotopes were aged in ethanol, generally without additional preparations, using a light microscope at magnification 32 with side illumination on a dark background. Otoliths of the fish from the cold stenotherm biotope were substantially smaller than those from the other locations and had numerous irregular hyaline structures. Therefore, their ageing was more difficult and required further preparation. Otoliths were embedded



Fig. 1. Sampling locations in the Baltic Sea. GoF, GoR, and BP - Gulf of Finland, Gulf of Riga, and Baltic Proper, respectively. 1 - eurytherm biotope, 2 - cold stenotherm biotope, $\operatorname{tr}-\operatorname{transition}$ area between the two distinct biotopes. 
into paraffin and ground on one side to provide good visibility of the structures (Svedäng et al., 1997). Age-readings of all otoliths were performed in duplicate. In cases the two readings differed, the ageing was repeated.

Growth curves of the fish were calculated using the following von Bertalanffy formulas:

length-at-age:

$$
L_{t}=L_{\text {inf }}\left[1-\exp \left(-k\left(t-t_{0}\right)\right)\right] \text {, and }
$$

weight-at-age:

$$
W_{t}=W_{\text {inf }}\left[1-\exp \left(-k\left(t-t_{0}\right)\right)\right]^{3},
$$

where $\quad L_{t}$ and $W_{t}$ - length and weight at age $t$, respectively;

$k$ - growth coefficient (a measure of the rate at which maximum size is reached);

$t_{0}$ - the theoretical age at zero length/weight.

As the length and weight curves exhibited similar patterns, only the length-at-age curves are presented. In addition, 20 embryos per female in a late stage of pregnancy (189 fish) from three different sub-areas were measured for length (precision $1 \mathrm{~mm}$ ) and weight (balances: Sartorius PT 120, precision $10 \mathrm{mg}$ ).

For the determination of absolute fecundity (number of embryos per female), we counted embryos at a late stage of pregnancy. Dead embryos (very small and with changed colour or pale) were discarded. In total, 189 gravid fish were analysed.

A total of 645 stomachs of two-year-old and older eelpout containing food were analysed. The whole stomach content was investigated. Percentages of the occurrence of various prey components in eelpout stomachs were calculated.

The number of vertebrae was counted in 924 individuals (120-135 per sampling location) caught in spring 1997-1999. The first vertebra counted linked to the interface of the occipital bone and, as a characteristic feature, its corpus was notably shorter than the next one. The last vertebra counted started from the last vertebral interface and reached the end of the skeleton.

Sampling locations were ranked according to productivity and salinity conditions by using available literature information (unpublished data of the Estonian Marine Institute; HELCOM, 2002).

\section{RESULTS}

Von Bertalanffy length-at-age growth curves exhibited substantial differences between biotopes. As a common feature, eelpout showed higher length-at-age values in eurytherm than in cold stenotherm conditions. In the transition area between these two distinct environments, somatic growth of the fish displayed intermediate values (Fig. 2). However, the lengths and weights of embryos at late stages of pregnancy did not show significant differences (Kruskal-Wallis test, $p>0.05$ ) between different biotopes in a basin or within similar biotopes in different basins. Within similar biotopes, the length-at-age values of the species 

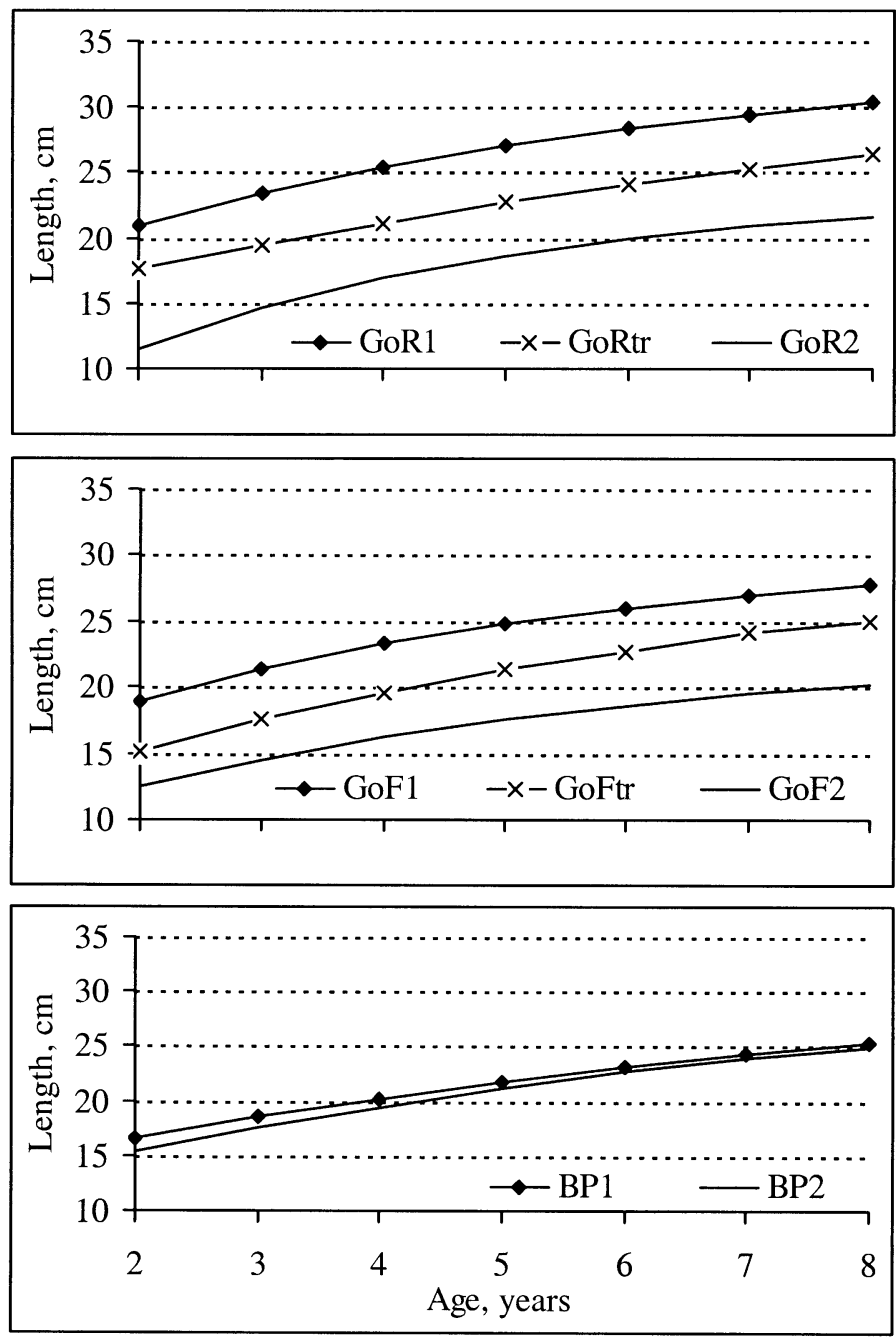

Fig. 2. Computed von Bertalanffy length-at-age growth curves of eelpout in different locations of the Baltic Sea. Legend as in Fig. 1.

were considerably higher in more productive than in less productive sampling sites (e.g., $L_{\mathrm{GoR} 1}>L_{\mathrm{BP} 1}, L_{\mathrm{BP} 2}>L_{\mathrm{GoR} 2}$, respectively).

Gravid females at late stages of pregnancy were found in all deep and shallow locations sampled in late autumn and early winter, suggesting that reproduction of the fish takes place both within these distinct biotopes and their transition areas. The absolute fecundity of the fish, expressed as the number of embryos, was strongly dependent upon female length. Normal distribution and constant variance of the data along the regression line was achieved by fitting the sigmoidal curve for ln-transformed data (Fig. 3). The regression coefficient $\left(R^{2}\right)$ varied from 

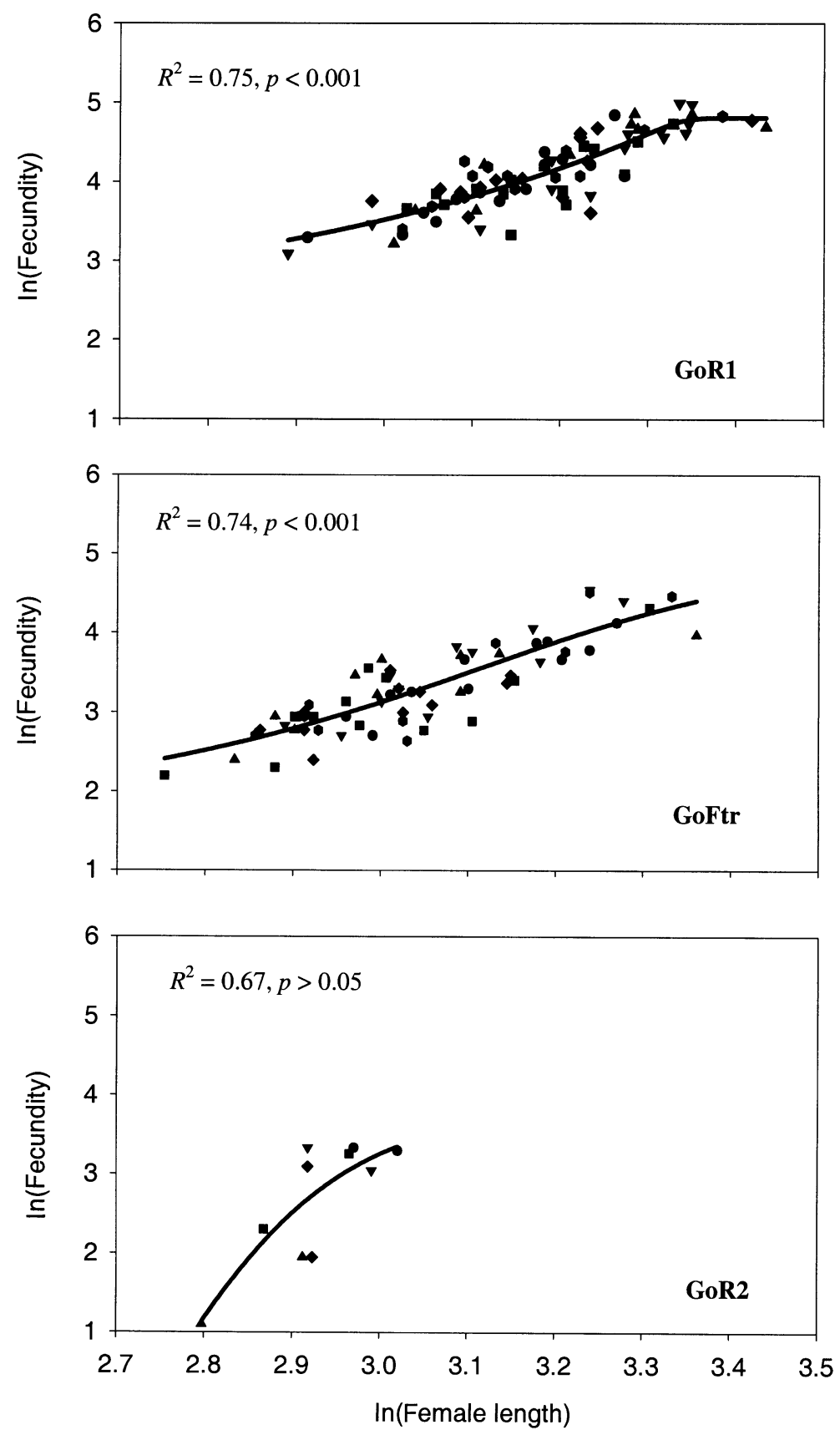

Fig. 3. Relationship between the number of embryos at late stages of pregnancy (as a measure of the absolute fecundity) and female length in three different sampling locations. GoR1 - eurytherm biotope of the Gulf of Riga, GoFtr - transition area between different biotopes in the Gulf of Finland, and GoR2 - cold stenotherm biotope in the Gulf of Riga. The fitted curve represents sigmoidal regression line for the ln-transformed data. 
0.67 to 0.75 with the relationship being significant in locations GoR1 and GoFtr $(p<0.001)$. Significant differences in eelpout fecundity between different locations (ln-transformed data, $t$-test, $p<0.05$ ) suggest that eelpout is more fecund in shallow areas than in the original cold stenotherm conditions (variability range of fecundity 13-147 and 3-28 embryos per female, respectively). In the eurytherm biotope, the fish attains sexual maturity at age 2 . All $2+$ females were found to carry embryos in late autumn and winter whereas most females (over 60\%) did not in the cold stenotherm conditions.

In total, 18 different food items were identified in eelpout stomachs. Substantial differences in the diet composition of the fish occurred between different biotopes. In eelpout stomachs in the cold stenotherm conditions (GoF2, GoR2, BP2), typical glacial relicts Pontoporeia spp. and Saduria entomon dominated. The shares of the remaining food categories identified were of minor importance (Table 1). In the eurytherm biotope (GoR1), the diet of eelpout was more diverse,

Table 1. Qualitative composition (percentage of occurrence of various taxa) of eelpout stomachs in different locations in the Baltic. GoF, GoR, and BP - Gulf of Finland, Gulf of Riga, and Baltic Proper, respectively. 1 - eurytherm biotope, 2 - cold stenotherm biotope, $\operatorname{tr}-\operatorname{transition}$ area between the two distinct biotopes

\begin{tabular}{l|c|c|c|c|c}
\hline \multirow{2}{*}{ Food } & \multicolumn{5}{c}{ Area (number of fish with non-empty stomachs analysed) } \\
\cline { 2 - 6 } & $\begin{array}{c}\text { GoF2 } \\
(92)\end{array}$ & $\begin{array}{c}\text { GoR2 } \\
(84)\end{array}$ & $\begin{array}{c}\text { BP2 } \\
(69)\end{array}$ & $\begin{array}{c}\text { GoFtr } \\
(255)\end{array}$ & $\begin{array}{c}\text { GoR1 } \\
(92)\end{array}$ \\
\hline \multirow{2}{*}{ Macoma } & 11.6 & 1.8 & 23.7 & 85.5 & 52.8 \\
Mytilus & 2.3 & - & 5.3 & 2.4 & - \\
Cardium & - & - & - & - & 11.3 \\
Balanus & - & - & - & 0.4 & - \\
Hydrobia & - & - & - & 0.4 & - \\
Total & $\mathbf{1 4 . 0}$ & $\mathbf{1 . 8}$ & $\mathbf{2 8 . 9}$ & $\mathbf{8 8 . 3}$ & $\mathbf{6 4 . 1}$ \\
\hline Saduria & 83.7 & 25.0 & 65.8 & 6.3 & 24.5 \\
Monoporeia & - & - & 7.9 & - & - \\
Pontoporeia & 4.7 & 69.6 & - & - & - \\
Corophium & - & 3.6 & - & - & 5.7 \\
Isopoda & - & - & 13.2 & - & - \\
Mysis & - & - & - & 7.5 & - \\
Crangon & - & - & - & 5.5 & - \\
Gammarus & - & - & - & - & 1.9 \\
Ostracoda & 2.3 & - & - & - & - \\
Total & $\mathbf{9 0 . 7}$ & $\mathbf{9 8 . 2}$ & $\mathbf{8 6 . 8}$ & $\mathbf{1 9 . 3}$ & $\mathbf{3 2 . 1}$ \\
\hline Herring & 7.0 & 1.8 & 15.8 & 3.5 & 15.1 \\
Gobies & - & - & - & 18.0 & - \\
Sticklebacks & - & - & - & - & 5.7 \\
Smelt & - & 1.8 & - & - & 3.8 \\
Cyprinids & - & - & - & - & 1.9 \\
Total & $\mathbf{7 . 0}$ & $\mathbf{3 . 6}$ & $\mathbf{1 5 . 8}$ & $\mathbf{2 1 . 5}$ & $\mathbf{2 6 . 5}$ \\
& & & & & \\
\end{tabular}


consisting mostly of eurytherm euryhaline invertebrates (mainly the bivalve Macoma balthica) with notable contributions of S.entomon and fish. Fragments of several fishes (herring, smelt, cyprinids) in eelpout stomachs probably belonged to adult stages of those species. In the transition area between the two distinct biotopes (GoFtr), the diet composition of the fish was substantially more diverse than in the cold stenotherm biotope. Eelpout stomachs contained both eurytherm euryhaline (mostly M. balthica, but also Monoporeia affinis, Balanus improvisus, Mytilus edulis, Crangon crangon, Hydrobia ulvae, Jaera albifrons, Idothea baltica) and cold stenotherm (Saduria entomon, Mysis spp.) invertebrates and in notable proportions also demersal fish (Pomatoschistus spp., Table 1).

In general, a higher number of vertebrae developed in the cold stenotherm biotope than in eurytherm conditions at high temperatures during the early stages of intraovarian development (Fig. 4). This pattern was especially obvious by subbasins with statistically significant differences observed between GoR and BP (Kruskal-Wallis test, $p<0.001$ ). Additionally, eelpout vertebrae counts differed significantly between similar biotopes in different sub-basins (BP2> GoR2 \& GoF2; GoR1 < BP1 \& GoF1, Kruskal-Wallis test, $p<0.001)$. Spatial differences

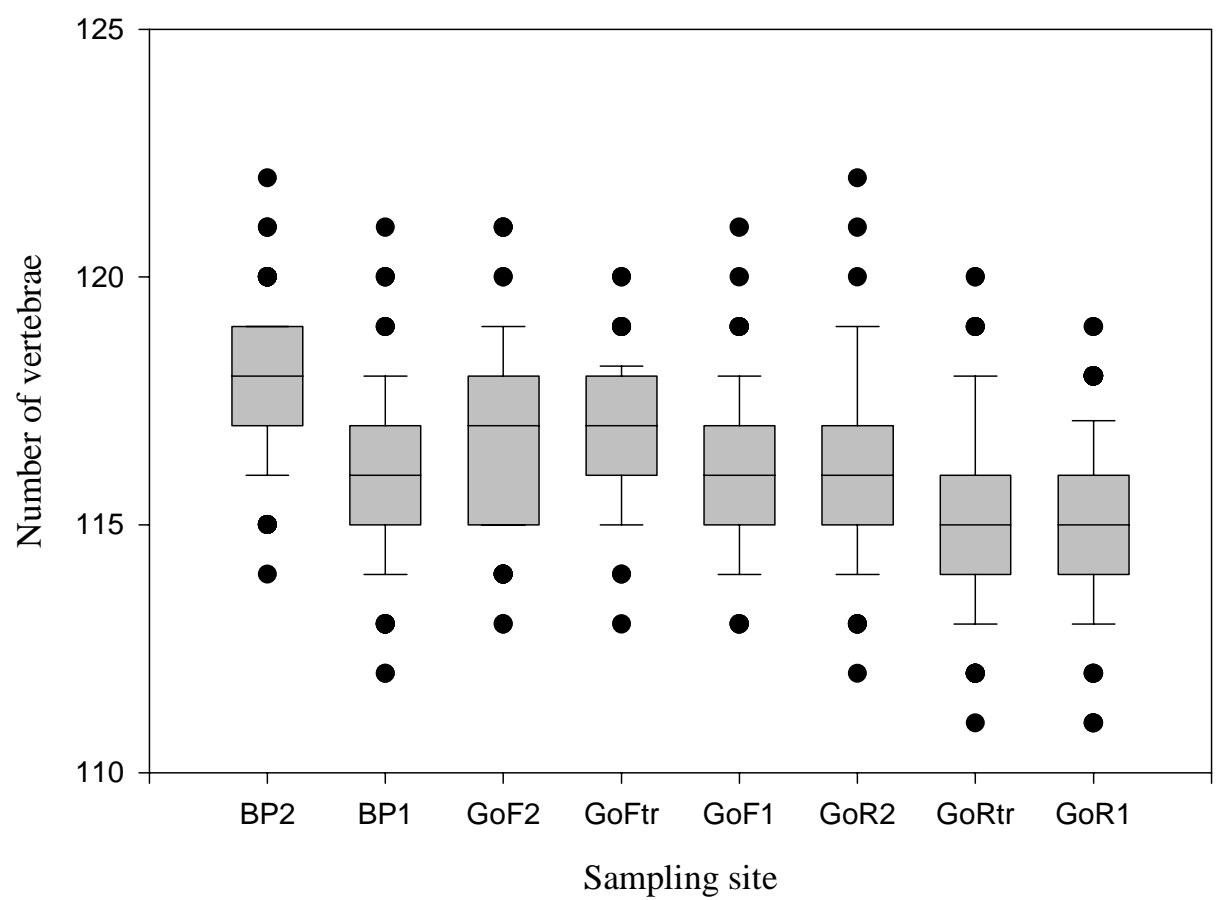

Fig. 4. Box-plots of eelpout vertebrae counts for different sampling sites in the northeastern part of the Baltic Sea. The solid line in the box represents the median abundance. The top and bottom edges of the box are the 25th and 75th percentile values, respectively. The whiskers represent the 10th and 90th percentile values, and the solid dots are outliers. For legend see Fig. 1. 
in eelpout vertebrae counts could partly be explained by the salinity regime as a highly significant positive correlation between these parameters was found (Spearman rank correlation, $R^{2}=0.88, p<0.001$ ). However, whether salinity is the proximate cause or indirectly points to a spatial heterogeneity of eelpout stock structure needs further detailed studies.

The change of the originally cold stenotherm character of the fish and colonization of a more productive eurytherm environment has led to higher postembryonal somatic growth rate and, most importantly, enhanced fecundity in the new environment. This enables the fish to increase in abundance and should facilitate, in general, higher success of survival. Colonization of eurytherm conditions was achieved by an adaptation process, which probably took place in the transition area between the two distinct biotopes at the coastal slope - the region where the seasonal thermocline occurs. The driving force for breaking down the original temperature barrier and colonization of shallow areas is probably more abundant and diverse food supply for the fish in these regions. As a result, compared to the original unit of the stock, the phenotype and possibly also the genotype of the species has changed. However, the presence of a spatially separated population below the seasonal thermocline confirms the original cold-water preference of the fish at the species level. This group has retained its stenothermic nature and possesses good prospects for survival as long as the necessary abiotic (temperature, oxygen content) and biotic (complex of glacial relicts as prey) conditions persist.

\section{DISCUSSION}

Occurrence and distribution of marine and freshwater fishes in the Baltic Sea are mainly governed by salinity conditions: marine species are mostly confined to open and southern Baltic whereas freshwater organisms are more important in coastal areas and northeastern parts (Voipio, 1981). The third very important component of the Baltic fauna (incl. invertebrates and vertebrates) is glacial relicts (Järvekülg, 1962; Segerstråle, 1966). In addition to the results presented in this study, marine and freshwater fish have also been shown to display adaptations that allowed them to maintain populations in the brackish Baltic Sea. Recent examples include the originally freshwater ruffe Gymnocephalus cernuus (Vetemaa \& Saat, 1996) and marine dab Limanda limanda, plaice Pleuronectes platessa, and flounder Pleuronectes flesus (Nissling et al., 2002).

In general, higher length-at-age values of eelpout were observed in the shallow areas (eurytherm conditions). These regions are generally characterized by elevated biological productivity with more complex environment and higher biodiversity (Kostrichkina, 1968; Gaumiga \& Lagzdinsh, 1995). The situation was also reflected in stomach contents of eelpout - the highest species diversity of the diet was recorded in this region. Within this biotope, the growth rate of eelpout followed the decrease in the biological productivity of the sampling sites: the highest growth of the fish was recorded in the most productive location (GoR1) and the weakest 
in the area of the lowest productivity (BP1). Eelpout exhibited the lowest lengthat-age and weight-at-age values in the cold stenotherm biotope. These areas are generally characterized by lower productivity in the Baltic Sea (Kostrichkina, 1968; Gaumiga \& Lagzdinsh, 1995). There (GoR and GoF) glacial relicts strongly dominated in eelpout stomachs. At steep slopes of the cold stenotherm biotope (BP2), the somatic growth rate (and also dietary diversity) of the fish exceeded that of the less productive deep areas (GoR2, GoF2), but was still notably lower than in the eurytherm biotope in productive coastal areas. Thus, the growth rate dynamics of sedentary demersal eelpout generally matched with the biological productivity of the sampling sites.

The two distinct biotopes are separated from each other by the seasonal thermocline, which is formed in spring at ca. $10 \mathrm{~m}$ and descends by the end of the warm season to ca. $30 \mathrm{~m}$ depth (Ojaveer, 1997). This depth range on the coastal slope with a highly changeable environment is probably the crucial location where the breaking of the temperature barrier and adaptation of the originally stenotherm eelpout to new eurytherm conditions took place. There the natural selection is probably the highest: only individuals with the ability to tolerate the eurytherm environment will survive. Within this region eelpout exhibited intermediate somatic growth rate and fecundity values.

In the eurytherm as well as in the cold stenotherm biotope the diet of eelpout contained substantial amounts of glacial relicts (especially Saduria entomon). Although the distribution of $S$. entomon was originally confined to cold-water layers (Järvekülg, 1973), the species is successfully adapted and abundantly present in shallow areas of eurytherm conditions (Kotta \& Kotta, 1995) facing permanently high temperatures during the warm season. Therefore we suggest that simultaneous or earlier adaptation of the evolutionarily determined prey of eelpout - the cold stenotherm invertebrate complex - to eurytherm conditions should be considered as an important factor for successful colonization of shallow areas by the fish. However, as evidenced by the current study, in shallow areas eelpout consumes very actively also eurytherm molluscs and invertebrates and some fishes. Although some zoarcid fish (two-line eelpout Bothrocara brunneum) are capable to some degree of prey specialization (Ferry, 1997), the wide food spectrum of eelpout at species level by incorporating in addition to the evolutionarily determined prey (cold stenotherm invertebrates) also euryhaline eurytherm invertebrate prey resources and various fishes in shallow areas points to the fact that eelpout may be a generalist in terms of food. This is probably very important for the utilization of the very rich prey field in the eurytherm biotope. Our suggestion that a richer food supply is probably the reason for the development of a separate population of this glacial relict species in a warm-water environment is consistent with earlier studies performed by Hansson (1980). He concluded that temporal occurrence of the fourhorned sculpin above the seasonal thermocline in summer in the Gulf of Bothnia is due to food limitation in deeper areas.

As previous studies in eelpout growth rate were not performed by the distinct biotopes identified in the current study, but were rather made on geographic 
basis, comparative analysis of growth rates with other areas in the Baltic Sea are lacking. Draganik \& Kuczynski (1993) reported the average length of eelpout in experimental trawl catches at 20-80 m depth, which generally decreased with depth in the Gulf of Gdansk. It is also evident that eelpout grows notably larger in the Gulf of Gdansk than in the NE Baltic Sea. Eelpout length-at-age data recorded within the current study are, in general, in agreement with values obtained by Kristoffersson \& Oikari (1975) and data summarized by them from other literature sources, although certain differences do occur. This may partly be explained by differences in the interpretation of the otolith structures (Svedäng et al., 1997). The discrepancies may also be due to differences in local environmental conditions, i.e. biological productivity.

We found that absolute fecundity of viviparous eelpout generally increased with increasing female length similarly to oviparous fishes (e.g., Burd \& Howlett, 1974; Kosior et al., 1996; Trella, 1998; Gundersen et al., 2001). The close dependence of the number of embryos and female body length for eelpout was reported in earlier studies (Götting, 1976; Jacobsson et al., 1993). However, these suggested other relationships (second order and linear, respectively) than suggested within the current study (sigmoidal). This might be due to different methodology (substantially lower precision of fish length measurement by Jacobsson et al. (1993)) and relatively small sample size (Götting, 1976). Statistically significant differences in the fecundity of eelpout in the sampling sites point to the fact that in addition to higher growth rate, sedentary demersal fishes are on average more fecund in the eurytherm (more productive) biotope compared to the cold stenotherm (less productive) environment. As mentioned earlier, all $2+$ females were found to be gravid in shallow regions whereas a substantial portion (over 60\%) did not carry embryos in autumn-winter in the cold stenotherm environment. Thus, differences in fecundity between different biotopes are even more pronounced than revealed by the data presented in Fig. 3 .

As found in previously conducted studies (M. Vetemaa, unpubl.), embryonal somatic growth did not correlate with female length. Thus, newly-born fry are of similar size both in the eurytherm and stenotherm environment. However, at age 2 substantial length-at-age differences were recorded: somatic growth of the species was the highest in the eurytherm and the lowest in the stenotherm environment. Thus, significant differences in the somatic growth-rate of the fish are probably created immediately after switching to exogenous feeding. In an evolutionary perspective, this has facilitated a higher chance for survival of the species (elevated growth rate of younger age groups) and probably reduction of the size-dependent predation mortality of younger stages. However, the fact that intraovarian growth of eelpout did not differ by biotopes suggests that embryonal development of the fish is not influenced during adaptation to new conditions.

The number of vertebrae is determined during the early stages of fish development. It is to a high degree genetically controlled and directly influenced by water temperature (Clark \& Vladykov, 1960; Hempel \& Blaxter, 1961; Hulme, 1995; Løken \& Pedersen, 1996). The critical period for vertebrae develop- 
ment of eelpout is July-September, the period after the fertilization of the fish (Tanasijchuk, 1970). At this time a strong seasonal thermocline separates the upper warm-water layers (temperature can exceed $20^{\circ} \mathrm{C}$ ) from the cooler water (temperature usually below $6^{\circ} \mathrm{C}$ ) beneath it. The number of vertebrae of eelpout was significantly higher in deep areas than in shallow areas. This finding is in agreement with results on other fishes (e.g., Garside, 1966). However, significant spatial differences in the mean number of vertebrae in similar biotopes may point to the fact that other factors than temperature during the early stages of development are additionally responsible for the formation of the number of vertebrae. These may include salinity (as a highly significant correlation was found between the number of vertebrae and water salinity) and/or reflect genetic differentiation (Frydenberg et al., 1973). However, the causative factor should be investigated in further studies. Therefore, results from the vertebrae studies do not allow us to draw any firm conclusions, and possibly point to even more complex nature of the eelpout stock structure than revealed by the somatic growth rate, feeding ecology, and fecundity studies alone.

On the basis of genetic analyses Christiansen et al. (1976) concluded that eelpout is a very sedentary fish and able to adapt to the local environment. Our observations support this statement by suggesting that eelpout might be even more limited in migration than thought earlier (instead of ca $50 \mathrm{~km}$ less than $20 \mathrm{~km}$ ) and further point to a need for genetic studies of the fish by the distinct biotopes in various sub-basins of the Baltic Sea.

\section{ACKNOWLEDGEMENT}

The current study was funded by the Estonian Governmental fundamental research project 0182579s03 and the Estonian Science Foundation grant No. 5930.

\section{REFERENCES}

Burd, A. C. \& Howlett, G. J. 1974. Fecundity studies on North Sea herring. J. Cons. int. Explor. Mer., 35, 2, 107-120.

Christiansen, F. B., Frydenberg, O, Hjorth, J. O. \& Simonsen, V. 1976. Geographic variation at the three phosphoglucomutase. Hereditas, 83, 245-256.

Clark, J. C. \& Vladykov, V. D. 1960. Definition of haddock stocks of the northwestern Atlantic. Fish. Bull., 169, 283-292.

Draganik, B. \& Kuczynski, J. 1993. Spatial distribution of the flounder and viviparous eelpout in the inshore waters of the Gulf of Gdansk. ICES C.M. 1993/J:13.

Elmgren, R. 1984. Trophic dynamics in the enclosed, brackish Baltic Sea. Rapp. P.-v. Reun. Cons. int. Explor. Mer., 183, 152-169.

Ferry, L. A. 1997. Food habits of the two-line eelpout (Bothrocara brunneum: Zoarcidae) at two deep-sea sites in the eastern North Pacific. Deep-Sea Res., 44, 521-531.

Fisher, P., Rademacher, K. \& Kils, U. 1992. In situ investigations on the respiration and behaviour of the eelpout Zoarces viviparus under short-term hypoxia. Mar. Ecol. Progr. Ser., 88, 181184. 
Frydenberg, O., Gyldenholm, A. O., Hjorth, J. O. \& Simonsen, V. 1973. Genetics of Zoarces populations. III: Geographic variations in the esterase polymorphism Est III. Hereditas, 73, 233-238.

Garside, E. T. 1966. Developmental rate and vertebral number in salmonids. J. Fish. Res. Board Can., 23, 1537-1551.

Gaumiga, R. \& Lagzdinsh, G. 1995. Macrozoobenthos. In Ecosystem of the Gulf of Riga between 1920 and 1990 (Ojaveer, E., ed.), pp. 198-211. Estonian Academy Publishers, Tallinn.

Götting, K. J. 1976. Fortpflanzung und Oocyten-Entwicklung bei der Aalmutter (Zoarces viviparus) (Pisces, Osteichthyes). Helgoländer Wiss. Meeresunters., 28, 71-89.

Gundersen, A. C., Roenneberg, J. E. \& Boje, J. 2001. Fecundity of Greenland halibut (Reinhardtius hippoglossoides Walbaum) in East Greenland waters. Fish. Res., 52, 229-236.

Hansson, S. 1980. Distribution of cod as a possible factor regulating the vertical distribution of fournhorn sculpin (Myoxocephalus quadricornis L.) in the Bothnian Bay. Ophelia Suppl., 1, 277-286.

HELCOM 2002. Environment of the Baltic Sea Area 1994-1998. Balt. Sea Environ. Proc., No $82 \mathrm{~B}$.

Hempel, G. \& Blaxter, J. H. S. 1961. The experimental modification of meristic characters in herring (Clupea harengus L.). J. Cons. Perm. int. Explor. Mer., 26, 336-346.

Hjorth, J. P. \& Simonsen, V. 1976. Genetics of Zoarces populations. VIII. Geographic variation common to the polymorphic loci HbI and EstIII. Hereditas, 81, 173-184.

Hulme, T. J. 1995. The use of vertebral counts to discriminate between North Sea herring stocks. ICES J. Mar. Sci., 52, 775-779.

Jacobsson, A., Neuman, E. \& Olsson, M. 1993. The viviparous blenny as an indicator of effects of toxic substances. Swedish Environmental Protection Agency. Kustrapport, 6.

Järvekülg, A. 1962. To the question on arctic fauna and its history in the Baltic Sea. Okeanologiya, 2 (in Russian).

Järvekülg, A. 1968. Some regularities of distribution of zoobenthos in the northeastern part of the Baltic Sea. Rybokhozyaistvennye issledovanija v bassejne Baltijskogo morya, 4, 89-108 (in Russian).

Järvekülg, A. 1973. Distribution and ecology of local populations of benthic glacial relicts. Oikos Suppl., 15, 91-97.

Kosior, M., Grygel, W. \& Kuczynski, J. 1996. Changes in the absolute fecundity of the southern Baltic flounder Platichthys flesus (L.). Bull. Sea Fish. Inst. (Gdynia), 138(2), 15-27.

Kostrichkina, E. M. 1968. Feeding interactions of the fish in the Gulf of Riga. Rybokhozyaistvennye issledovanija v bassejne Baltijskogo morya, 4, 109-135 (in Russian).

Kotta, I. \& Kotta, J. 1995. The state of macrozoobenthos of Pärnu Bay in 1991 as compared to 1959-1960. Proc. Estonian Acad. Sci. Ecol., 5, 26-37.

Kotta, I. \& Kotta, J. 1999. Distribution and migration of mysids in the Gulf of Riga (Northern Baltic). Proc. Estonian Acad. Sci. Biol. Ecol., 48, 284-295.

Kristoffersson, R. \& Oikari, A. 1975. Notes on the biology of the eel-pout, Zoarces viviparus (L.) in the brackish water of Tvärminne, Gulf of Finland. Ann. Zool. Fenn., 12, 143-147.

Løken, S. \& Pedersen, T. 1996. Effect of parent type and temperature on vertebrae number in juvenile cod, Gadus morhua (L.), in northern Norway. Sarsia, 80, 293-298.

Neuman, E. 1982. Species composition and seasonal migrations of the coastal fish fauna in the southern Bothnian Sea. In Coastal Research in the Gulf of Bothnia (Müller, K., ed.), pp. 317 351. Dr. W. Junk Publishers, The Hague.

Nissling, A., Westin, L. \& Hjerne, O. 2002. Reproductive success in relation to salinity for three flatfish species, dab (Limanda limanda), plaice (Pleuronectes platessa), and flounder (Pleuronectes flesus), in the brackish water Baltic Sea. ICES J. Mar. Sci., 53, 93-108.

Ojaveer, H. 1997. Composition and dynamics of fish stocks in the Gulf of Riga ecosystem. Diss. Biol. Univ. Tartuensis, No. 31. Tartu University Press. 
Ojaveer, H., Lankov, A., Eero, M., Kotta, J., Kotta, I. \& Lumberg, A. 1999. Changes in the ecosystem of the Gulf of Riga from the 1970s to the 1990s. ICES J. Mar. Sci. Suppl., 56, 33-40.

Schmidt, J. 1917. Zoarces viviparus L. and local races of the same. C. R. Trav. Lab. Carlsberg, 13, 277-397.

Segerstråle, S. G. 1966. Adaptational problems involved in the history of the glacial relicts of Eurasia and North America. Rev. Roum. Biol. Zool., 11, 59-66.

Svedäng, H., Ojaveer, H. \& Urtans, E. 1997. Interpretation of the otolith structures in viviparous blenny Zoarces viviparus. J. Appl. Ichthyol., 13, 137-142.

Tanasijchuk, V. S. 1970. Biology of eelpout Zoarces viviparus (L.) of the Gulf of Riga. Trudy BaltNIIRH, 4, 161-170 (in Russian).

Trella, K. 1998. Fecundity of blue whiting (Micromesistus australis Norman, 1937) from the Falkland fishing grounds in the years 1983, 1984 and 1986. Bull. Sea Fish. Inst. (Gdynia), 144(2), 25-37.

Vetemaa, M. \& Saat, T. 1996. Effects of salinity on the development of fresh-water and brackishwater ruffe Gymnocephalus cernuus (L.) embryos. Ann. Zool. Fenn., 33, 687-691.

Voipio, A. (ed.) 1981. The Baltic Sea. Elsevier Oceanogr. Ser., 30. Elsevier Scientific Publishing Company, Amsterdam.

\title{
Emakala Zoarces viviparus mikroevolutsioon Läänemeres
}

\author{
Henn Ojaveer, Margit Eero ja Ain Lankov
}

Emakala Zoarces viviparus uuriti Läänemere kirdeosa erinevate alabasseinide (Liivi ja Soome laht ning Läänemere avaosa) erinevates biotoopides - eurütermne, külm stenotermne ja nende üleminekuala. Kala somaatilise kasvu, absoluutse viljakuse ja selgroolülide arvu olulised erinevused erinevates biotoopides viitavad emakala erinevate populatsioonide esinemisele Läänemere kirdeosas. Esialgselt külma stenotermse emakala kohanemine eurütermse elukeskkonnaga on võimaldanud liigil elama asuda kõrgema toitelisusega madalas rannikumeres ja seega suurendada liigi arvukust. Olulisteks eeltingimusteks kala eelmainitud kohanemisele uutele temperatuuritingimustele on (1) kahe selgelt eristuva biotoobi üleminekuala esinemine (koht, kus toimus adaptatsioon) ja (2) kohanemisele eelnenud või ka samaaegne külma stenotermset keskkonda eelistavate põhjaselgrootute kompleksi (emakala toit) kohastumine eurütermsete keskkonnatingimustega. Adaptatsiooni tulemusena on emakalal toimunud fenotüübilised muutused; kala embrüonaalne kasv ei ole aga kohanemisprotsessis mõjutatud. 